\title{
Inventory Management Practices and the Effectiveness of the Supply Chain of Essential Medicines in the Public Sector. Evidence from Six Selected Public Hospitals in Uganda
}

\author{
John Charles Okiria ${ }^{1}$, Richard Mwirumubi ${ }^{2}$ K. A. Mpaata ${ }^{3}$ \\ ${ }^{1}$ School of Post Graduate Studies and Research Nkumba University Uganda
}

\begin{abstract}
This study assessed the relationship between the Inventory management practices and the effectiveness of the downward supply chain of essential medicines in the selected 6 public hospitals in Uganda. A cross sectional descriptive and analytical survey was done with both qualitative and quantitative data collected. Two hospitals were regional referral and the four were general hospitals by level of care. Overall the study found a significant relationship between the level of inventory practices in the hospitals and the effectiveness of the downward supply chain. The study therefore recommends improvement on the ordering practices to cater for lead time and the buffer stock, use of adjusted consumption method, improve on the monitoring, procurement planning and adherence to the essential medicines list of Uganda when ordering
\end{abstract}

Keywords: Inventory, supply chain, stores management, medicines, effectiveness

\section{Introduction}

Supply chain effectiveness plays a significant role in the performance of any organization. According to the WHO (2010) report, the quality of the pharmaceutical services in Uganda public sector has remained low. This is inspite the Uganda Health sector budget allocation improvement that has been evident over the last few years from $8.9 \%$ of the GDP to currently $9.6 \%$ of the GDP though still below the Abuja Declaration of $15 \%$, donations, the Decentralization policy in which is meant to take services nearer to the people, the introduction of the Credit Line where money is paid direct to the supplier by Government and facilities just order what they need, direct delivery to the facility by the supplier.

According to the Uganda Annual Health Sector Performance Report (AHSPR 2013) only 49\% of the health facilities did not have out of stock of the tracer medicines. Generally there are still acute unexplained shortages of essential medicines, delayed deliveries, expiry of essential medicines, concerns about quality of the medicines in the facilities and accumulation of unwanted and expired medicines (Katabaazi J.N, Kitutu F.E, et al,. (2010). this has been majorly been associated with the supply chain MOH (2011). The outcomes of these phenomena among others include reduction in the utilization of the public hospitals, poor treatment outcomes, and even incidences of occurrence of fatal cases. However, according to the observation by Kearney A.T. Inc (2004) the supply chain effectiveness could be improved upon by quality medical stores management practices.

Good Inventory management practices in the hospitals is one of the critical aspects that influence the effectiveness of the downward supply chain of medicines (MSH 2010), and a potential area of efficiency gains. This study therefore assessed the relationship between Inventory management practices in the hospital and the effectiveness of the down ward supply chain.

\section{Methodology}

The study adopted a descriptive and analytical cross sectional survey, with mixed research methods approach, (Onwuegbuzie \& Johnson, (2006); Greene (2006); Greene, Caracelli, and Graham (1989); Gray (2004). The study assessed the relationship between Inventory management practices and the effectiveness of the downward supply chain of medicines in the selected public hospitals in Uganda. Both quantitative and qualitative data collection methods were used. Standardized checklists, interviewer guide and questioners were used to collect data. A total of 6 purposively selected hospitals were studied with all pharmacy, medical stores and hospital heads as purposively selected respondents. Principal Component Analysis was carried out on the indicators using both Factoring out principle component and Varimax Rotation. Chi square tests were then applied.

In order to adduce evidence from the data collected, univariate, bivariate and multivariate analysis were done and table 1 below shows the measures of the effectiveness that were considered in the study. These twelve indicators were proposed as measures for the dependent variable and a principal component analysis was done to determine a factor that measured best the effectiveness of the supply chain. Factor Analysis was also done to determine the possible independent variables that influence the dependent variable

Data was collected by use of questioners, observation checklists and interviews from all the six health facilities studied. However, the preceding part presents the demographic characteristics of the purposively selected respondents who provided the qualitative information. 


\section{International Journal of Science and Research (IJSR) \\ ISSN (Online): 2319-7064 \\ Index Copernicus Value (2013): 6.14 | Impact Factor (2015): 6.391}

\section{Results}

Demographic characteristics of the respondents

The study was conducted in six hospitals; these were Abim, Atutur, Kawolo and Bwera General Hospitals and Fort Portal, Soroti Regional Referral hospitals. Of the 38 purposively selected respondents only four persons did not respond to the study giving a response rate of $92.1 \%$. However, of the 35 who responded only 30 provided both qualitative and quantitative information and the other 4 provided only qualitative information. Of the 30 who responded 11 (36.7\%) were from the Regional Referral Hospitals and the 19 (63.3\%) were from the General Hospitals and the highest number of persons who were handling medicines were under others 10 (33.3\%) under these are the volunteers, nurses and non-qualified persons. This observation raises concerns to whether these persons are competent enough to handle medical stores as they are not qualified and lack basic knowledge in handling medical stores.

On the aspect of experience, the highest percentage of 46.6\% had worked in their current jobs for more than 11 years .However; majority $57.1 \%$ had not gotten any related training in the last 6 months

As in table 1 all the six facilities had stock cards, goods receipt notes, issue vouchers delivery note and requisition vouchers except the bin cards in place. However, most of the stock cards were not updated, some missing and some incompletely filled. It is important to note that in order to be able to have meaningful information on the levels and the status of medicines in the hospitals updated stock cards is a must.

A completely filled stock card should have the name of the medicine, the strength, manufacturer date, expiry unit of package batch number, quantity received and the date of receipt, quantity issued out the date and to where, issue voucher number, balance at hand and remarks where necessary and should be kept for each type of medicine.

Table 1: Inventory documents in place in the studied hospitals

\begin{tabular}{|c|c|c|c|}
\hline Indicator document & YES & $\mathrm{NO}$ & STATUS \\
\hline Bin cards & & $\checkmark$ & Not in use \\
\hline Stock cards & $\checkmark$ & & Most Not updated \\
\hline Goods receipt notes & $\checkmark$ & & \multirow{4}{*}{$\begin{array}{c}\text { Most not filed well } \\
\text { and some copies } \\
\text { missing }\end{array}$} \\
\hline Issue vouchers & $\checkmark$ & & \\
\hline Delivery notes & $\checkmark$ & & \\
\hline Requisition vouche & $\checkmark$ & & \\
\hline
\end{tabular}

\section{Hospitals ordering practices}

The current system in place for public health facilities in an attempt to improve on the availability of EMHS in the facilities entails the use of a -cedit line", where government pays the money allocated to each hospital/facility for medicines directly to the supplier in this case the National Medical Stores and the hospitals just make orders. This has been improved upon by the introduction of the procurement plans that are supposed to enhance planning by the supplier to ensure that all that the hospitals have planned is in place in terms of type and quantity.

Below is an extract from the NMS analysis of the levels of adherence of hospitals to their procurement plans when ordering medicines.

Table 2 shows the average variance between the procurement planed medicines and the actual orders made. The variance characteristically is both in the form of ordering above the planned amounts and in some cases below the planned amount as in the procurement plan. This greatly affects the availability of medicines in both the supply stores as well as the hospital stores.

The implications of this non-adherence to the procurement plans and yet National Medical Stores strictly supplies according to plan means medicines which are not included in the procurement plan will not be supplied and even if they were in the procurement plan and the amount ordered was more than the amount in the procurement plan only the amount in the procurement plan will be supplied. The challenge here may be that the planned estimates may have just been guess estimates not scientifically determined using either the morbidity patterns or the consumption methods since the capacity to quantify medicines at the facilities is generally lacking (MSH 2009).

However, this high level of non-adherence to the procurement plans could actually be from the dynamic characteristics of the disease conditions in terms of seasons and epidemics which may render the quantified essential medicines and health supplies appear inaccurate. So whereas the procurement plans are meant to enhance the planning in ensuring availability of essential medicines and health supplies, there is need for more flexibility and training of the stores and pharmacy staff in medicines and health supplies quantification in order to minimize avoidable stock outs of medicines. 


\section{International Journal of Science and Research (IJSR) ISSN (Online): 2319-7064}

Index Copernicus Value (2013): 6.14 | Impact Factor (2015): 6.391

Table 2: Ordering practices by the studied Regional Referral Hospitals

\begin{tabular}{|c|c|c|c|c|c|c|c|}
\hline Hospital & Indicator medicine & Planned & Ordered & Issued & Ordered & \% Variance issued & Order Status \\
\hline \multirow{4}{*}{ Soroti } & Artemether (24) tablets & 1800 & 1800 & 1200 & 100.0 & 66.7 & Within Range \\
\cline { 2 - 8 } & Amoxicillin 250mg & 1080 & 1080 & 720 & 100.0 & 66.7 & Within Range \\
\cline { 2 - 8 } & Cotrimoxazole 480mg tablets & 1020 & 780 & 680 & 76.5 & 66.7 & Under Ordered \\
\cline { 2 - 8 } & Mebendazole 100mg tablets & 60 & 50 & 40 & 83.3 & 66.7 & Within Range \\
\cline { 2 - 8 } & Paracetamol 500mg & 1200 & 1200 & 800 & 100.0 & 66.7 & Within Range \\
\cline { 2 - 8 } & Co-packaged ors and zinc tablets & 1200 & 1800 & 600 & 150.0 & 50.0 & Over Ordered \\
\hline \multirow{4}{*}{ Fort Portal } & Artemether (24) & 3000 & 600 & 800 & 20.0 & 26.7 & Under Ordered \\
\cline { 2 - 8 } & Amoxicillin 250mg capsules & 1750 & 1028 & 828 & 58.7 & 47.3 & Under Ordered \\
\cline { 2 - 8 } & Cotrimoxazole 480mg tablet & 1250 & 330 & 250 & 26.4 & 20.0 & Under Ordered \\
\cline { 2 - 8 } & Mebendazole 100mg tablets & 20 & 54 & 32 & 270.0 & 160.0 & Over Ordered \\
\cline { 2 - 8 } & Oral rehydration salts for 1lt & 50 & 160 & 40 & 320.0 & 80.0 & Over Ordered \\
\cline { 2 - 8 } & Paracetamol 500mg tablets & 600 & 700 & 650 & 116.7 & 108.3 & Within Range \\
\hline
\end{tabular}

In table 3 below the order status of some of the indicator medicines indicate unknown. For example Mebendazole 100mg in Kawolo and Bwera hospitals list indicate unknown meaning that this medicine was not planned for procurement by the hospital and yet they actually ordering for it. Mebendazole is a medicine for worm infestation, it is an essential medicines and affordable and kills $90 \%$ of the common worm infestation among persons and is the cheapest available. It ought have not been missed in the procurement plan. So whereas NMS could have procured these items on the basis of the procurement plans once they are not requested by the hospitals they run a risk of the medicines expiring at the National Medical Stores. Or the only other alternative is to supply it according to the plan even if there is probably a genuine reason why the hospital had left it out when ordering. This dilemma makes the supply chain appear less effective as many of the items not ordered are probably supplied and those that are ordered but not in the procurement plan are not supplied in terms of quantities required. There is therefore need to develop a harmonized strategy to deal with this supply chain challenge that seems to affect both the hospitals and the supplier NMS.

This big discrepancy between the planned medicines and the actual orders made by the hospitals also negates the benefits of procurement planning. This is because by the fact that these items were not included in the procurement plan it meant that they were not needed and therefore the supplier had no business to procure for the hospital. This anomaly of ordering medicines and supplies that were not in the procurement plan technically increases the proportion of drugs not supplied and therefore taken to be out of stock at the hospital and yet could have been procured had the necessary planning been done.

Table 3: Ordering practices by the General Hospitals studied

\begin{tabular}{|c|c|c|c|c|c|c|c|}
\hline Hospital & Indicator medicine & Planned & Ordered & Issued & Ordered (\%) & Variance issued (\%) & Order Status \\
\hline \multirow{6}{*}{ Kawolo } & Artemether( 24) & 996 & 405 & 226 & 40.7 & 22.7 & $\mathrm{UO}$ \\
\hline & Amoxicillin 250mg & 672 & 576 & 324 & 85.7 & 48.2 & WR \\
\hline & Cotrimoxazole $480 \mathrm{mg}$ tablets & 480 & 350 & 235 & 72.9 & 49.0 & $\mathrm{UO}$ \\
\hline & Mebendazole $100 \mathrm{mg}$ tablets & 0 & 40 & 0 & & & $\mathrm{U}$ \\
\hline & Oral rehydration salts for $1 \mathrm{lt}$ & 300 & 350 & 200 & 116.7 & 66.7 & WR \\
\hline & Paracetamol 500mg & 720 & 560 & 360 & 77.8 & 50.0 & $\mathrm{UO}$ \\
\hline \multirow{7}{*}{ Bwera } & Artemether ( 24) & 500 & 600 & 400 & 120.0 & 80.0 & WR \\
\hline & Amoxicillin 250mg capsules & 600 & 950 & 600 & 158.3 & 100.0 & $\mathrm{OO}$ \\
\hline & Co-packaged ors and zinc tablets & 1500 & 700 & 600 & 46.7 & 40.0 & $\mathrm{UO}$ \\
\hline & Cotrimoxazole $480 \mathrm{mg}$ & 250 & 130 & 130 & 52.0 & 52.0 & UO \\
\hline & Mebendazole 100mg & 0 & 2 & 0 & & & $\mathrm{U}$ \\
\hline & Oral rehydration salts for $1 \mathrm{lt}$ & 25 & 0 & 0 & 0.0 & 0.0 & UO \\
\hline & Paracetamol 500mg tablets & 250 & 530 & 380 & 212.0 & 152.0 & $\mathrm{OO}$ \\
\hline \multirow{7}{*}{ Aturtur } & Artemether ( 24) & 2400 & 539 & 405 & 22.5 & 16.9 & $\mathrm{UO}$ \\
\hline & Amoxicillin 250mg caps & 600 & 830 & 550 & 138.3 & 91.7 & $\mathrm{OO}$ \\
\hline & Cotrimoxazole $480 \mathrm{mg}$ tablet & 300 & 170 & 130 & 56.7 & 43.3 & UO \\
\hline & Mebendazole 100mg tab & 12 & 35 & 30 & 291.7 & 250.0 & $\mathrm{OO}$ \\
\hline & Paracetamol 500mg tablet, & 600 & 1050 & 660 & 175.0 & 110.0 & $\mathrm{OO}$ \\
\hline & Co-packaged ors and zinc tablets & 1500 & 3700 & 900 & 246.7 & 60.0 & $\mathrm{OO}$ \\
\hline & Oral rehydration salts for & 30 & 190 & 106 & 633.3 & 353.3 & $\mathrm{OO}$ \\
\hline \multirow{7}{*}{ Abim } & Artemether (24) & 450 & 480 & 365 & 106.7 & 81.1 & WR \\
\hline & Amoxicillin 250mg cap & 510 & 430 & 285 & 84.3 & 55.9 & WR \\
\hline & Co-packaged ors and zinc tablets & 1800 & 1900 & 900 & 105.6 & 50.0 & WR \\
\hline & Cotrimoxazole $480 \mathrm{mg}$ & 240 & 230 & 60 & 95.8 & 25.0 & WR \\
\hline & Mebendazole 100mg & 24 & 19 & 15 & 79.2 & 62.5 & UO \\
\hline & Oral rehydration salts for 1lt & 90 & 210 & 15 & 233.3 & 16.7 & $\mathrm{OO}$ \\
\hline & Paracetamol 500mg & 456 & 540 & 341 & 118.4 & 74.8 & WR \\
\hline
\end{tabular}

Key: WR= Within Range; OO=Over Ordered; UO= Under Ordered; U=Unknown Source: Secondary Data 2013/2014(NMS) 


\section{International Journal of Science and Research (IJSR) ISSN (Online): 2319-7064 \\ Index Copernicus Value (2013): 6.14 | Impact Factor (2015): 6.391}

\section{Supply factors in relation to order fulfillment and timeliness}

According to the records by NMS and the qualitative evidence by the general manager the order fulfillment rate as per the procurement plans is almost $100 \%$. However, the major variance is brought by the hospitals ordering for medicines that they did not include in their procurement plans. Or order more quantities than what was indicated in the procurement plan.

\section{Hypothesis test results}

$H_{O}$ There is no significant relationship between current inventory management practices and the effectiveness of the supply chain of essential drugs,
The chi square test was used at 5\% level of significance, to test whether the variables of interest for each set of hypothesis had a significant relationship with the outcome variable or not. Further tests were also done to determine the extent to which the significant variables, were responsible for the variations in the outcome variable. This was done for each variable at a time, in the absence of a confounding factor.

The outcome variable that was taken to be the best presenter of any confounding factors among the group of variables that moved out to measure -ffectiveness of supply chain" was variable No out of stock of essential medicines in the hospitals"

Table 4: Average monthly consumption and no out of stock of essential medicines in the hospitals"

\begin{tabular}{|c|c|c|c|c|c|c|c|}
\hline \multirow[t]{2}{*}{ Variable } & \multirow{2}{*}{ Indicator } & \multicolumn{6}{|c|}{ No out of stock of essential medicines in the hospitals } \\
\hline & & **Agree & $* *$ Disagree & Total & O.R & $\chi^{2}$ & P-value \\
\hline \multirow{3}{*}{$\begin{array}{l}\text { Average monthly consumption } \\
\text { in determining the amount to } \\
\text { order }\end{array}$} & Agree** $^{* *}$ & 18 & 8 & 26 & \multirow[b]{3}{*}{2.25} & \multirow[b]{3}{*}{10.81} & \multirow[b]{3}{*}{0.005} \\
\hline & Disagree** & 2 & 2 & 4 & & & \\
\hline & Total & 20 & 10 & 30 & & & \\
\hline
\end{tabular}

$\boldsymbol{R}^{2}=0.984 t=-0.067$

Agree $^{* *}=$ agree + strongly agree, Disagree**= strongly disagree+ Disagree

Variable average monthly consumption in determining the amount to order was found to be significantly associated with no out of stock for essential medicines since the $\chi^{2}$ value $=10.81>$ the test value of 3.864 and the same conclusion was arrived at by looking at the p-value of 0.005 which is less than $5 \%$ or 0.05 test value. In the same test, allowing only this variable to vary variable -No out of stock of essential medicines in the hospitals", the fitting showed that in the absence of all the other variables in the model, the effect of variable average monthly consumption in determining the amount to order would be responsible of $\mathbf{9 8 . 4 \%}$ of the total variations that would be observed in "no out of stock of essential medicines in the hospitals". As regards the odds ratio (OR), Hospitals which were putting into use their Average monthly consumption data in determining the amount of medicine to order were 2.25 times more likely not to encounter situation of having essential medicine being out of stock as compared to those hospitals that were not using average monthly consumption in determining the amount of medicine to order (Table 4).

The significance of this variable is in line with Neelam Sekhri Centre for Global Development (2006) report which highlights the importance of use of information in decision making in the procurement of medicines. So therefore there is need for hospitals to use the average monthly consumption in determining amounts to order as this provides a more scientific estimate of medicines to be ordered. However, there is need to adjust this monthly consumption for out of stocks if this has to make a meaningful intervention in enhancing the effectiveness of the supply chain which in this case is being measured by the variable "no out of stock of essential medicines in the hospitals".

Table Error! No text of specified style in document.: EMLU use and "no out of stock of essential medicines in the hospitals"

\begin{tabular}{|c|c|c|c|c|c|c|c|}
\hline Variable & \multirow{2}{*}{ Indicator } & \multicolumn{6}{|c|}{ "no out of stock of essential medicines in the hospitals" } \\
\hline \multirow{4}{*}{$\begin{array}{l}\text { Essential medicines list being } \\
\text { considered when determining } \\
\text { what to order }\end{array}$} & & $* *$ Satisfactory & **Unsatisfactory & Total & O.R & $\chi^{2}$ & P-value \\
\hline & Agree** & 6 & 16 & 22 & \multirow{3}{*}{0.38} & \multirow{3}{*}{10.79} & \multirow{3}{*}{0.0054} \\
\hline & Disagree $^{* *}$ & 4 & 4 & 8 & & & \\
\hline & Total & 5 & 20 & 30 & & & \\
\hline
\end{tabular}

As shown in table 5 above, variable -essential medicines list being considered when determining what to order was found to be significantly associated with variable "no out of stock of essential medicines in the hospitals". This is because the $\chi 2$-value for this test was 10.79 which is greater than the test value of 3.864 and the same conclusion was also arrived at by looking at the p-values $=0.0054<0.05$. Upon assessment of the percentage variation this variable can cause in the outcome variable in the absence of other variables, the fitting showed that this variable would be responsible for
$91.2 \%$ of the total variations one can observe in variable "no out of stock of essential medicines in the hospitals".

It also means that, Hospitals which were using or considering their essential medicines list when determining what to order during the medicine ordering time were 0.38 times less likely to encounter situations of essential medicines being out of stock using such lists during the medicine ordering time. In other words, the likely hood of observing essential medicine being out of stock is 0.38 times less likely to occur in hospitals which were using their 


\section{International Journal of Science and Research (IJSR) \\ ISSN (Online): 2319-7064 \\ Index Copernicus Value (2013): 6.14 | Impact Factor (2015): 6.391}

essential medicine lists during medicine ordering time as compared to those health facilities that were not using such lists.

This is in line the Ministry of Health emphasis that only medicines in the essential medicines list should be ordered by public health facilities as this enhances availability of essential medicines in the facilities by limiting the choice to what has been enlisted as essential for the level of care. It therefore the important that public health facilities adhere to the essential medicines list in order to minimize out of stock of essential medicines in the facilities. Essential medicines list is premised on the fact that different countries have different disease patterns and there are several medicines that are being promoted by pharmaceutical manufacturers daily at high costs but probably with no significantly different efficacy and also limitedly available.

Table 6: Consumption levels being used and "no out of stock of essential medicines

\begin{tabular}{|c|c|c|c|c|c|c|c|}
\hline Variable & \multirow[t]{2}{*}{ Indicator } & \multicolumn{6}{|c|}{ "no out of stock of essential medicines in the hospitals" } \\
\hline \multirow{4}{*}{$\begin{array}{l}\text { Consumption levels } \\
\text { are used to } \\
\text { determine medicines } \\
\text { requirements }\end{array}$} & & **Satisfactory & **Unsatisfactory & Total & O.R & $\chi^{2}$ & P-value \\
\hline & Agree** $^{* *}$ & 5 & 6 & 11 & \multirow{3}{*}{2.3} & \multirow{3}{*}{4.837} & \multirow{3}{*}{0.003} \\
\hline & Disagree** & 5 & 14 & 19 & & & \\
\hline & Total & 10 & 20 & 30 & & & \\
\hline
\end{tabular}

$R^{2}=0.766$

As regards variable 'consumption levels are used to determine medicines to order, the study showed that this variable is significantly associated with variable "no out of stock of essential medicines in the hospitals". This is because the $\chi^{2}$-value $=4.837>3.864$ and the same conclusion was arrived at by comparing the $\mathrm{p}$-value $=0,003<0.05$

Attempt of assess the extent to which this variable would vary alone the outcome variable "no out of stock of essential medicines in the hospitals", the analysis showed that in such a situation, $76.6 \%$ of the variations in out of stock of essential medicine would be as a result of its dependence on consumption levels being used to determine amount of medicines
Using the odds ratio the analysis showed that hospitals which were using Consumption levels in determining medicines requirements for their health facilities were 2.3 times more likely to have their essential medicines in stock all the time as compared to those that were not using their consumption levels (Table 6). Consumption levels relate to the daily amounts of medicines that patients consume and this is factored in to determine the average monthly consumption. As the daily consumption shows the usage of medicines on daily basis it may also be used to monitor weekly consumption trends.

Table 7: Amount of budget and no out of stock of essential medicines

\begin{tabular}{|c|c|c|c|c|c|c|c|}
\hline Variable & \multirow[t]{2}{*}{ Indicator } & \multicolumn{6}{|c|}{ "No out of stock of essential medicines in the hospitals" } \\
\hline \multirow{4}{*}{$\begin{array}{l}\text { Amount of budget } \\
\text { allocated dictates } \\
\text { amount to order }\end{array}$} & & $* *$ Satisfactory & **Unsatisfactory & Total & O.R & $\chi^{2}$ & P-value \\
\hline & Agree** & 5 & 20 & 25 & \multirow{3}{*}{0.38} & \multirow{3}{*}{11.01} & \multirow{3}{*}{0.0000} \\
\hline & Disagree** $^{* *}$ & 2 & 3 & 5 & & & \\
\hline & Total & 3 & 10 & 30 & & & \\
\hline
\end{tabular}

$R^{2}=0.607$

Variable amount of budget allocated dictates amount to order" was found to be significant variable in explaining out of stock of essential medicines since $\chi^{2}$-value $=11.01>$ the test value 3.864 and the same conclusion was arrived at by comparing p-value of $0.0000<0.05$

The assessment of the extent to which the variable amount of budget allocated dictates amount to order" if left single handedly in the model to vary the outcome variable "no out of stock of essential medicines in the hospitals", as shown by the coefficient of determination i, $60.7 \%$ of the total variation in variable - ot of stock of essential medicine - -uld be as a result of its dependency on amount of budget allocated.

Hospitals that were not having budgetary limitations for medicines were 0.38 times less likely to encounter the situations of out of stock of essential medicines. The probable reason for this low odds ratio of 0.38 can scientifically be explained in the terms of medicines selection/ choice. Whereas you may have a big budget but the selection of medicines to be procured is not in line with the needs, in appropriate supplies will be procured which may not be essential to the needs of the patients leading to the stocking of 'necessary' medicines but not vital or essential medicines. So it is evident that it not necessarily how much money but selection of what to procure and determine how much to procure of a given medicine that is key.

These findings explain the role average monthly consumption, adherence to the essential medicines list and considerations of the consumption levels as stronger factors in the availability of medicines as shown by the coefficients of determination of $0.98,0.91$ and 0.77 respectively as compared to 0.61 of the budget as a factor in determination of no out of stock of medicines. Hospitals therefore should not base all the out of stock of medicines which in case was used to as an indicator for supply chain effectiveness as a reason for not ensuring the availability of medicines. The role of the stores and pharmacy personnel skills, knowledge and abilities are therefore key in this aspect (Table 7). 


\section{International Journal of Science and Research (IJSR) \\ ISSN (Online): 2319-7064}

Index Copernicus Value (2013): 6.14 | Impact Factor (2015): 6.391

Table 8 Pharmacist advice and no out of stock of essential medicines

\begin{tabular}{|c|c|c|c|c|c|c|c|}
\hline Variable & \multirow{2}{*}{ Indicator } & \multicolumn{6}{|c|}{ No out of stock of essential medicines in the hospitals } \\
\hline \multirow{4}{*}{$\begin{array}{l}\text { Orders are } \\
\text { always made with } \\
\text { advice of } \\
\text { pharmacist }\end{array}$} & & **Satisfactory & **Unsatisfactory & Total & O.R & $\chi^{2}$ & P-value \\
\hline & Agree** & 6 & 6 & 12 & \multirow{3}{*}{2.6} & \multirow{3}{*}{1.66} & \multirow{3}{*}{0.806} \\
\hline & Disagree** & 5 & 13 & 18 & & & \\
\hline & Total & 11 & 19 & 30 & & & \\
\hline
\end{tabular}

\section{$R 2=0.001$}

Considering the variable -orders are always made with advise of pharmacist" the study found this as not a significant factor in explaining "no out of stock of essential medicines in the hospitals" since its $\chi^{2}=1.66<3.864$ and the same conclusion was arrived at since the p-value $=0.806>$ 0.05 ,the coefficient of determination is almost zero meaning that there is no variation expected in out of stock for essential medicine, that is coming as a result of its dependency on -rders are always made with advise of pharmacist (Table 8).

Whereas appears ironical, in practice it may be explainable that if the persons ordering medicines follow the essential medicines list and the records provided the amounts consumed, less technical details will be required to determine actual amounts of medicines required hence less need for a higher cadre at that level. In addition by the fact that out of stock occurs in facilities with or without pharmacists could be a factor beyond stores management alone but as a result of other factors. As it is a known fact that the advice of the pharmacist may not necessarily add for financial resources for medicines for example and rarely involved in the actual recording and dispensing of medicines.

However, not all that is insignificant is unimportant factor. A fact that the tests has shown to contrary does not mean the pharmacists advice is irrelevant since this just one of the several role he/she has to play. Secondly other factors may have shadowed the effect of the pharmacist competence.

Table 9: All ordered items supplied and no out of stock of essential medicines

\begin{tabular}{|c|c|c|c|c|c|c|c|}
\hline Variable & \multirow[t]{2}{*}{ Indicator } & \multicolumn{6}{|c|}{ "No out of stock of essential medicines in the hospitals } \\
\hline \multirow{4}{*}{$\begin{array}{l}\text { Facility gets all } \\
\text { the ordered items } \\
\text { from supplier }\end{array}$} & & **Satisfactory & **Unsatisfactory & Tota & O.R & $\chi^{2}$ & P-value \\
\hline & Agree** & 10 & 3 & 13 & \multirow{3}{*}{25} & \multirow{3}{*}{14.082} & \multirow{3}{*}{0.0000} \\
\hline & Disagree** & 2 & 15 & 17 & & & \\
\hline & Total & 12 & 18 & 30 & & & \\
\hline
\end{tabular}

$R^{2}=0.913$

Variable facility gets all the ordered items from supplier was found to be significant in explaining variable "no out of stock of essential medicines in the hospitals" , this is because the $\chi^{2}=14.082>$ the test value of 3.864 and the same conclusion was arrived at by considering the p-value of 0.0000 which is less than the test value of 0.05 .

In addition considering the extent to which this variable, if left single handedly to vary the outcome variable, $91.3 \%$ of the variations of the outcome variable no out of stock of essential medicines will be a result of its effect. From the findings the primary determinant of out of stock is the order fulfillment and therefore need to design strategies or means of ensuring that the level of order fulfillment is $100 \%$. Considering the Chi-test, hospitals which were getting all the ordered items from supplier" were 25 times more likely to have essential medicines in stock as compared to the health facilities which were found to say that they were not getting all the ordered items from supplier (Table 9)

Annual sector performance reports (2010/2011; 2011/2012) and the report by the Joint Review Meeting (2011) highlighted the NMS inability to sometimes supply all the items ordered by the facilities. This has contributed to the out of stock of some of the essential medicines in the facilities. However, according to NMS this inability to sometimes fail to supply the ordered medicines was mainly due to the fact that health facilities do not adhere to the procurement plans that were agreed upon and yet NMS procures its supplies according to the aggregate procurement plans for the health facilities. Orders that are out of the procurement plan will not be served by the supplier. So there is need for coordination among multiple stakeholders (Kraiselburd and Yadav, 2013).

However, whereas this is technically true and shows a high level of need for proper planning, disease patterns and conditions are dynamic necessitating a flexible supply chain. This view is in support of Martin and Hellen, (2004), who observed that because most markets and market needs are uncertain and turbulent, there is therefore need for supply chains to adopt a more resilient system which ensures continuous availability of supplies in health facilities at all times. Nakyanzi, et al., (2010) too observed the need for a resilient supply chain more so in the health care organizations where live is a commodity of concern. They highlighted the need for continuous availability of emergency medicines, and consideration of the high level of potency to expire, diverse scope of need, unpredictable disease patterns and events.

Chauduri, et al., (2010), reported that -ay country will continue to face severe challenges in improving access to EMHS for its population if it continues to rely on foreign exporting companies outside the country. They argued that in order to improve access, governments need to strengthen and develop potential of local companies to manufacture medicines locally and reap from savings from profits that would be gained by foreign countries that export medicines to them. This could be one of the strategies the Ugandan government could try and adopt as currently Investment 


\section{International Journal of Science and Research (IJSR) \\ ISSN (Online): 2319-7064 \\ Index Copernicus Value (2013): 6.14 | Impact Factor (2015): 6.391}

Authority is putting in place all the necessary conditions to attract investors.

Table 10: Safety stock consideration and no out of stock of essential medicines

\begin{tabular}{|c|c|c|c|c|c|c|c|}
\hline Variable & \multirow[t]{2}{*}{ Indicator } & \multicolumn{6}{|c|}{ "No out of stock of essential medicines in the hospitals" } \\
\hline \multirow{4}{*}{$\begin{array}{l}\text { Safety stock is } \\
\text { considered when } \\
\text { determining amount } \\
\text { to order }\end{array}$} & & **Satisfactory & **Unsatisfactory & Total & O.R & $\chi^{2}$ & P-value \\
\hline & Agree** & 10 & 16 & 26 & \multirow{3}{*}{0.63} & \multirow{3}{*}{11.508} & \multirow{3}{*}{0.0040} \\
\hline & Disagree** & 2 & 2 & 4 & & & \\
\hline & Totals & 12 & 18 & 30 & & & \\
\hline
\end{tabular}

$\mathbf{R}^{2}=\mathbf{0 . 9 2 2}$

As shown in table 10, the variable Safety stock is considered when determining amount to order", was found to be significantly associated with variable "no out of stock of essential medicines in the hospitals", this is because, the $\chi^{2}=11.508>3.864$, which is the test values at $5 \%$ confidence level and this same conclusion was arrived at by looking at the p-value of 0.004 which is less than 0.05 . Hospitals which considered safety stock when determining the amount to order have 0.63 less chances of having no out of stocks of essential medicines.

Safety stock in essence is supposed to cover for the uncertainties which include among others delayed supplies and changes in consumption patterns. So the fact that these hospitals that do not consider this risk at most times having essential medicines out of stock as there naturally occurring changing disease patterns and even hospital utilization patterns. However, in situations where the budgets even do not allow procurement of the actual requirements, the possibility of considering safety stock is limited. A multidimensional approach is therefore required to minimize the levels of out of stocks of essential medicines.

Considering the value of the coefficient of determination $\left(\mathbf{R}^{2}=\mathbf{0 . 9 2 2}\right)$, we can conclude that if this variable is allowed to vary the outcome variable "no out of stock of essential medicines in the hospitals" alone, then $92.2 \%$ of the total variation in out of stock of essential medicine that will be observed will be as a result of its dependency on variable $\rightarrow$ sfety stock is considered when determining amount to order". This finding scientifically shows the strength safety stock has in influencing the availability of medicines in hospitals and also shows the dynamic and unpredictable nature of health and health care consumption patterns. The supply chain will at all times appear to be ineffective if the hospitals do not have safety stocks to cater for emergencies, unavoidable delays that tend to increase the lead time.

\section{Multivariate Analysis}

In order to assess the relationship between the medical stores management practices which was the independent variable and the effectiveness of the supply chain of essential medicines which was the dependent variable, all the factors of the three constructs that were significant at bi-variate level were subjected to a multivariate analysis using logistic regression model. A Back Ward Stepwise Logistic Regression was used to control for all probable confounding variables in the test.

Hypothesis, "there is a significant relationship between the inventory management practices and the effectiveness of the supply chain. All the inventory management factors that were tested were found to be significantly related the effectiveness of the supply chain (Table 11).

Table 11: Inventory management practices and Supply chain effectiveness

\begin{tabular}{|c|c|c|c|c|c|}
\hline & Variable & Response & Adjusted OR & 95\% CI Adjusted OR & p-Value \\
\hline 1 & $\begin{array}{l}\text { Average monthly consumption used to determine the } \\
\text { amount to order }\end{array}$ & $\begin{array}{c}\text { Agree* } \\
\text { Disagree* }\end{array}$ & 2.7 & $1.35-4.70$ & $0.000 * *$ \\
\hline 2 & Consumption level are used to determine medicine required & $\begin{array}{c}\text { Agree* } \\
\text { Disagree* }\end{array}$ & 2.2 & $1.43-3.52$ & $0.000 * *$ \\
\hline 3 & $\begin{array}{l}\text { Essential medicines list is considered when determining } \\
\text { what to order }\end{array}$ & $\begin{array}{c}\text { Agree* } \\
\text { Disagree* }\end{array}$ & 0.61 & $-0.02-0.87$ & $0.0024 * *$ \\
\hline 4 & $\begin{array}{l}\text { Safety stock is considered when determining amount to } \\
\text { order }\end{array}$ & $\begin{array}{c}\text { Agree* } \\
\text { Disagree* }\end{array}$ & 0.66 & $-0.230-0.890$ & $0.000^{* *}$ \\
\hline 5 & Amount of budget allocation dictates amount to order & $\begin{array}{c}\text { Agree* } \\
\text { Disagree* }\end{array}$ & 0.32 & $-0.01-0.76$ & $0.0001^{* *}$ \\
\hline 6 & The facility receives all the order items from the supplier & $\begin{array}{c}\text { Agree* } \\
\text { Disagree* }\end{array}$ & 27 & $18.40-37.20$ & $0.000^{* *}$ \\
\hline 7 & $\begin{array}{c}\text { Average period from order generation to actual delivery of } \\
\text { medicines }\end{array}$ & $\begin{array}{c}\text { Agree* } \\
\text { Disagree* }\end{array}$ & 2.2 & $1.60-3.80$ & $0.020 * *$ \\
\hline 12 & Inventory not regularly being monitored, & $\begin{array}{c}\text { Agree* } \\
\text { Disagree* }\end{array}$ & 26.0 & $18.40-36.40$ & $0.0027 * *$ \\
\hline 13 & The budget determining size of purchases, & $\begin{array}{c}\text { Agree* } \\
\text { Disagree* }\end{array}$ & 0.28 & $-0.450-0.720$ & $0.0000^{* *}$ \\
\hline
\end{tabular}

\section{Conclusion}

There is significant relationship between Inventory management practices and the effectiveness of the downward supply chain of essential medicines $n$ the public sector. 


\section{International Journal of Science and Research (IJSR) \\ ISSN (Online): 2319-7064 \\ Index Copernicus Value (2013): 6.14 | Impact Factor (2015): 6.391}

\section{Recommendations}

1) Procurement should always expedite the approval process of medicine orders

2) Safety stock should always be considered when ordering for medicines

3) Budget allocation should be improved upon

4) Level Order fulfillment by NMS should be $100 \%$ however, there is need to look at the procurement plan strategy in or order to make it more resilient and accommodative.

5) Regularize inventory monitoring

6) Store card update for medicines should be done daily

7) Notifications for such medicines out of stock by NMS should also be done immediately.

\section{References}

[1] Agarwal A, Sharkar R (2002). Modeling supply chain performance variables. Asian academy of management. Vol.10(2): 47-68.

[2] Amin, M. E. (2005). Social Science Research: Conception, Methodology and Analysis. Kampala Makerere University Printery.

[3] Annual Health Sector Performance Report of Uganda (AHSPR 2013)

[4] Bamberger, M. (2000).Integrating quantitative and qualitative research in development projects: Direction in development series, Washington, DC: The World Bank

[5] Banker, R. D., I. R. Bardhan, et al., (2006). "Plant information systems, manufacturing capabilities, and plant perfor mance." MIS Quarterly 30(2): 315-337.

[6] Bardhan, I., J. Whitaker, et al. (2006). "Information Technology, Production Process Outsourcing, and Manufacturing Plant Performance." Journal of Management Information Systems 23(2): 13-40.

[7] Barney, (2012) Firms resources and and supply chain performance. Journal of Management.

[8] Barney, J. (1991). "Firm Resources and Sustained Competitive Advantage." Journal of Management 17(1): 99.

[9] Barney, J. (1991). Firm resources and sustained competitive advantage. Journal of Management, 17, 99-120.

[10] Barney, J. (1986). Resource-based theories of competitive advantage: A ten-year retrospective on the resource-based view. Journal of Management, 27, 643-650.

[11] Barratt M (2004). Understanding the meaning of collaboration in the supply chain. Supply. Chain. Management, 9(1): 31-42.

[12] Becker, C. et al., (2004) A dose of higher costs. Modern Healthcare 34(6) 4-11.

[13] Becker, G. S. (1983). Human capital: A theoretical and empirical analysis with special reference to education. Chicago, IL: University of Chicago Press.

[14] Black RE, Morris SS, Bryce J. Where and why are 10 million children dying every year? Lancet (2003);361: 2226-34. [PubMed]

[15] Boaduo, N. A. P. (2005). Methodological Choice and Application in a Research Study: A Framework for Practitioners. In the African Symposium, 5(3): 88-101.
[16] Boaduo, N. A. P. (2006). Methodological Choice and Application in a Research Study: A Framework for Practitioner in Lonaka: Bulletin of the Centre for Academic Development -Quality Assurance in Higher Education".

[17] Boyce, C. \& Neale, P. (2006) Conducting In-depth Interviews: A guide for Designing and conducting indepth interviews for evaluation input. Pathfinder International. Tool Series.

[18] Bryman, A. (2012). Social Research Methods (4 ${ }^{\text {th }}$ Ed.). Oxford University Press, New York.

[19] Bowersox, D. J., Closs, D.J. and Theodore, S.P (2000). "Ten Mega Trends That Will Revolutionalise supply chain Logistics", (21:2), 2000, pp. 1-16.

[20] Buchan, J and Dovlo, D., 2000. International recruitment of health workers to the UK: A report for DIFD.

http://www.difdhealthrc.org/shared/publications/report s/int_rec/int-rec-main.pdf

[21] Buren, H 2008. Fairness and the main management theories of the twentieth century: a historical review, 1900-1965. Journal of Business Ethics, 82(3), pp.663644.

[22] Chandler, A. D. (1962). Strategy and structure: Chapters in the history of American industrial enterprise. London, England: MIT Press.

[23] Chauduri. S., et al., (2010), Indian Generic Producers, access to Essential Medicines and local production in Africa. An Argument with reference to Tanzania European Journal of Development Research 22. 451468 Available at: http://www.pagravejournals.com/ejdr/journal/v22/n4/full/ejdr201027a.htm 1. Accessed 24.10.2014.

[24] Chen L, Evans T, Anand S, Boufford JI, Brown H, Chowdhury M, et al. (2004). Human resources for health: overcoming the crisis. Lancet 2004;364: 198490. [PubMed]

[25] Chibba,\& Rundqvist, (2011). Mapping flows - An analysis of the information flows within the integrated supply chain. Proceedings of the 16th Annual Conference for Nordic Researchers in Logistics

[26] Child, D. (1990). The essentials of factor analysis, second edition. London: Cassel Educational Limited.

[27] Churchill, G.A., (1979). A paradigm for developing better measures of marketing constructs. Journal of Marketing Research 16 (2), 64-73.

[28] Cigolini, et al. (2004) Supply chain efficiency in automobile industries(Oxford Press

[29] Coff, R. W. (2002). Human capital, shared expertise, and the likelihood of impasse on corporate acquisitions. Journal of Management, 28, 107-128.

[30] Combs, J., Liu, Y., Hall, A., \& Ketchen, D. (2006). How much do high-performance work Practices matter? A meta-analysis of their effects on organizational performance. Personnel Psychology, 59, 501-528.

[31] Copacino (1996). Performance of the Supply Chain of Medicines in ensuring availability of medicines.

[32] Council of Supply Chain Management Professionals (CSCMP 2006)

[33] Cronbach, L. J., (1951). Test validation. In: Thorndike, R.L. (Ed.), Educational Measurement, 2nd ed. 


\section{International Journal of Science and Research (IJSR) \\ ISSN (Online): 2319-7064}

Index Copernicus Value (2013): 6.14 | Impact Factor (2015): 6.391

American Council on Education, Washington, DC, pp. 443-507.

[34] Croom et al. (2000)The Impact of E-business on Supply Chain Management: an Empirical Study of Key Developments, International J. Operations and 36. Waller, M., M.E.

[35] Johnson and T. Davis, 1999. Production Management, 25(1): 55-73.

[36] Deininger K, Mpuga P. (2004) Abolition of user fees in the public sector: Enhanced uptake Health care services

[37] Dukes, G. (2005), Moving forward — now! Presented at the Strategies for Enhancing Access to Medicines Conference, Accra, Ghana, 20-22 June 2005. www.msh.org/seam/conference2005

[38] Eisen A (2005). Achieving a High-Performance Supply Chain: Sharing Information with Partners. Bus. Intelligence. J., 13(2): 29-37.

[39] Ember, C. R. \& Ember, M. (2001). Cross-Cultural Research Methods. New York:Rowman \& Littlefield.

[40] Emory, C.W., 1980. Business Research Methods. Richard D. Irwin, Homewood, IL.

[41] Fisher, J., \& Govindarajan, V. (1992). Profit center manager compensation: An examination of market, political and human capital factors. Strategic Management Journal, 13, 205-217

[42] Global Fund for HIV/AIDS, Tuberculosis and Malaria.(2005). HIV/AIDS, tuberculosis and Malaria: the status and impact of the three diseases. Geneva: Global Fund.

[43] Global Emergency Group. 2010.

[44] Golafshani, N. (2003). Understanding Reliability and Validity in Qualitative Research. The Qualitative Report 8(4): 597-607.

[45] Grant, R. M. (1991). The resource-based theory of competitive advantage: Implications for strategy formulation. California Management Review, 33, 114136.

[46] Grant, R. M. (1991). Prospering in dynamicallycompetitive environments: Organizational capability as knowledge integration. Organization Science, 7, 375387.

[47] Gray D. E. (2004).Doing Research in the Real World. London: SAGE Publications.

[48] Greene, J. C. (2006). Toward a methodology of mixed methods social inquiry. Research in the Schools, 13(1), 93-98.

[49] Greene, J. C., Caracelli,V. J., \& Graham,W. F. (1989). Toward a conceptual framework for Mixed-method evaluation designs. Educational Evaluation and Policy Analysis, 11, 255-274.

[50] Gustin CM, Daugherty PJ, Stank TP (1995). The effects of information availability on logistics integration. J. Bus. Logistics., 16(1): 1-21.

[51] Hambrick, D. C., \& Mason, P. A. (1984). Upper echelons: The organization as a reflection of its top managers. Academy of Management Review, 9, 193206.

[52] Hanke, J. \& Kassowiski, T. (2011). Comparison of Value of Pearson's and Spearman's Correlation Coefficients on the Same Sets of Data. Questiones Geographicae 30(2): 87- 93.
[53] Harris, D., \& Helfat, C. (1997). Specificity of CEO human capital and compensation. Strategic Management Journal, 18, 895-920

[54] John Kenneth Galbraith in (1969),Intellectual Capital in organizations. National Taipei University, R.O.C.

[55] Johnson \& Onwuegbuzie, (2004) Mixed research methods: A research Paradigm. Whose time has come? Vol 33 no 7 14-26 Sage Publishers.

[56] Kearney A.T. Inc, (2004); Improving the medicines supply chain

[57] Kiapi, S., (2009). What is Causing Drug Shortages in Uganda? A publication of the health rights advocate. Available at: http://healthrightsadvocate.blogspot.com/2009/05/what -is- causing-drug-shortages-in.html. Accessed on April 27, 2013.

[58] Kish, Leslie. (1965). Survey Sampling. New York: John Wiley and Sons, Inc.

[59] Koch and McGrath, (1996), Improving Labor productivity. Wiley on line library.

[60] Kogut \& Zander, (1992); Knowledge of the firm, combinative capabilities. Columbia University USA.

[61] Kothari, C. R. (2004). Research Methodology: Methods and Techniques ( $2^{\text {nd }}$ Ed.) New Age International (P) Limited Publishers. New Delhi.

[62] Kraiselburd and Yadav, (2013).Supply Chain and Global Health. An Imperative for bringing operations management into action.POM Vol. 22 Issue2 Page 377-381

[63] Kulkarni, Sarika \& Sharma, Ashok 2004. Supply chain management. Tata McGraw-Hill Publishing

[64] Kvale, D. (1996). An Introduction to Qualitative research Interviewing. London. SAGE Publications.

[65] Malhotra, N. K., Agarwal, J., \& Peterson, M. (1996). Methodological Issues in cross-Cultural Marketing Research: A state-of-the-art review. International Marketing

[66] Malhotra, M.K.. \& Grover, V. (2003). Transaction cost framework in operations and supply chain management research: theory and measurement. Journal of Operations Management, 21: 457-473.

[67] Martin C\& Hellen P. (2008) Building up a resilient supply chain. International Journal of Logistics. Emerald Group Publishing Limited

[68] Ministry of Health (2005), Health Sector Strategic Plan 2004/05-2009/10, Kampala, Uganda.

[69] Ministry of Health. (2010a). Health Sector Strategic and Investment Plan 2010/11-2014/15. Kampala.

[70] Ministry of Health.( 2010b). Status of Antiretroviral Therapy Service Delivery in Uganda. Kampala: AIDS Control Program, Ministry of Health

[71] Ministry of Health (2008), National Health Policy: Promoting People's Health to enhance Economic growth Economic Policy Research Centre (2010) Governing Health Service Delivery In Uganda: A Tracking Study Of Drug Delivery Mechanisms.

[72] Ministry of Health (2005, 2010): Management of Drugs and Supplies.

[73] Mitra, S. and A. K. Chayam (1996). "Analyzing costeffectiveness of organizations: The impact of information technology spending." Journal of Management Information Systems 13(2): 2 


\section{International Journal of Science and Research (IJSR) \\ ISSN (Online): 2319-7064 \\ Index Copernicus Value (2013): 6.14 | Impact Factor (2015): 6.391}

[74] Moberg CR, Cutler BD, Gross A, Speh TW (2002). Identifying antecedents of information exchange within supply chains. Int. J.Physical. Distribution. Logistics., 32(9): 755-770.

[75] Monczka RM, Petersen KJ, Handfield RB, Ragatz GL (1998). Success factors in strategic supplier alliances: The buying company perspective. Decision. Sci., 29(3): 553-577.

[76] Mugenda, O. M. \& Mugenda, A. G. (2003). Research Methods: Quantitative and Qualitative Approaches: African Technology Studies Centre, Kampala.

[77] Katabaazi J.N, Kitutu F.E, et al., (2010). Expiry of medicines in supply outlets in Uganda. SciELO Public Health Bull World Health Organ 2010; 88:154-158

[78] Krejcie, R. V., \& Morgan, D. W. (1970). Determining sample size for research activities. Educational and Psychological Measurement, 30, 607-610.

[79] National Drug Authority (2012). Essential Drug List.

[80] National Health Accounts (2007)

[81] Neelam Sekhri (2006). Center for Global Development report on why demand forecasting is not working in the current environment. (CGD).

[82] Ntayi et al,. (2007). Knowledge management and competitive advantage: The interactive effect of market orientation. Makerere business school Uganda.

[83] Ntayi, J.M., Gerrit, R., and Eyaa, S. (2008, 2009), supply chain Swiftness in a Developing Country: The Case of Uganda Small and Medium Sized Enterprises, E-Journal of Business and Economic Issues, Vol. IV, No. I.

[84] Nunnally, J.C., 1978. Psychometric Theory. McGrawHill, New York

[85] Onwuegbuzie, A. J. \& Combs, J. P. (2007). Data Analysis in Mixed Research. A Primer. International of Education 3(1): E13.

[86] Onwuegbuzie, A. J., \& Johnson, R. B. (2006). The validity issue in mixed research. Research in the Schools, 13(1), 48-63.

[87] Solis, Adriano 2001. The importance of information flow in supply chain management. .<http://www.utminers.utep.edu/solis

[88] Padmanabhan, V., \& Whang S, Lee H.L . (1997). The bullwhip effect in supply chains, Sloan Management Review, Spring: 93-102

[89] Sekaran U (2003) Research methods for business. A skill building Approach. Wiley and sons, Inc. new York

[90] SURE (2012). Securing Ugandans' Right to Essential Medicines at District level Sveiby, K.E, (1997). The new organization wealth. Beret Koehler Publishers Inc. San Franscisco CA

[91] Sweet, S. A. \& Grace-Martin, A. (2011). Data Analysis with SPSS: A First Course in Applied Statistics. Un-published Text, Cornell University

[92] Syracuse (287-212 BC) Archimedes archives. Discovery of the Cogwheel technology Tec Net (2008) Supply Chain of Essential Medicines.

[93] Towill D.R, Evans G.N., \& Cheema P. (1997) Analysis and design of an adaptive minimum reasonable inventory control system. Retrieved http://www.informaworld.com/smpp/content content= $\underline{\mathrm{a} 1713842805 \& \mathrm{db}=\mathrm{all}}$
[94] Truxillo, Catherine. (2003). Multivariate Statistical Methods: Practical Research Applications Course Notes. Cary, N.C.: SAS Institute.

[95] Uganda Private Health Sector Mapping report (2008)

[96] Uganda Investment Authority (2009) report

[97] World Health Organization.(2004) Medicines strategy: countries at the core 2004-2007.

[98]

http://whqlibdoc.who.int/hq/2004/WHO_EDM_2004.5 .pdf (accessed 26th Sept 2014).

[99] WHO. (2007)The world medicines situation. Geneva: World Health Organization, 2004.

[100] www.eldis.org/static/DOC17161.htm (accessed 22 Sep 2013). 